\title{
CBCT images of treatment of incisor rotation, canine transposition, lateral incisor orizzontal position and risk of canines impacted, as result of facial trauma in growing patient
}

\author{
Macrì M, Di Pilla Emanuela, Scarano A and Festa F* \\ Via Gabriele Veneziale 31, Isernia, Italy
}

Facial trauma in growing patient may cause excessive development of bone or can limit it because of scar tissue, mostly in growing centers such as condyle or alveolar bone. Earlier the trauma is, the more the injury is and it is hard to recognise functional and occlusal changes during growing period. Alveolar bone in children deforms after trauma but doesn't fracture [1].

If tooth follicle is injured, permanent tooth can be displaced, and it will be a problem its extrusion. Tooth follicle guides tooth extrusion [2].

In 2013, in the orthodontic department of G. D’Annunzio University, in Chieti (ITALY), an eleven years old girl refers to have hurt the left part of the superior jaw, falling off bike, when she was five years old. She has noticed that in her mouth there is something strange.

\section{Diagnosis and Treatment}

\section{Initial CBCT images}

OPT (Figure 1): all permanent teeth are present but their eruption is delayed - there are some decayed teeth and some deciduous roots fragments - the tooth 3.5 is already erupted (other inferior bicupids and canines are not erupted) - the upper right bicuspids are erupted ( the left ones are not erupted yet) - the tooth 1.3 risks to be impacted, due to its inclination and mesial position - the tooth 2.1 is $90^{\circ}$ rotated along its axis - the tooth 2.3 is transposed on the root of the tooth 2.2, which is horizzontally laying near bicuspid roots (Figure 2).

Tele RX: Normal facial height - second class skeletal pattern due to retrusive mandible - upper and lower incisors proclined - forward mandibular growing direction, changes toward clockwise rotation, due to upper and lower incisors contact - $3 \mathrm{~mm}$ overjet - $2 \mathrm{~mm}$ overbite Figure 3 and Table 1

Frontal RX: Inclined occlusal plane - mandibular right deviation (Figure 4)

\section{Palatal suture: Open suture (Figure 5)}

Temporo mandibular joint: Retropositioned, curved and flattened condyles (Figure 6)

\section{Extraoral photos: (Figure 7)}

Intraoral photos: Dental upper midline toward left - lower dental midline toward right (during opening mouth it is steel deflected) inclined occlusal plane - narrow upper dental arch (Figure 8)

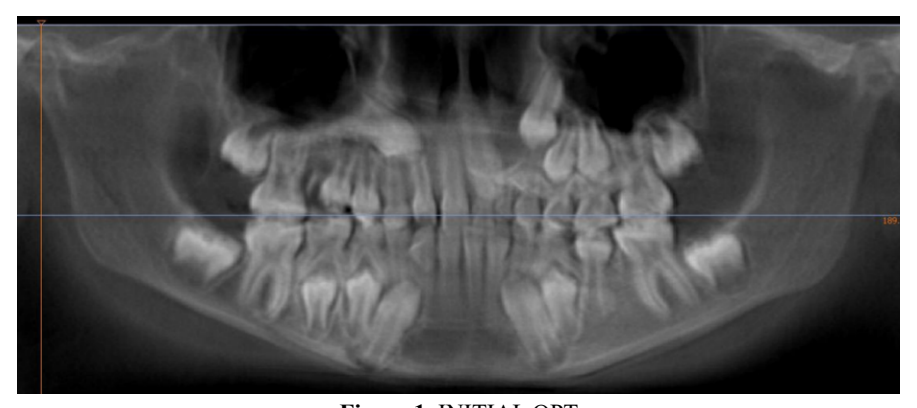

Figure 1. INITIAL OPT

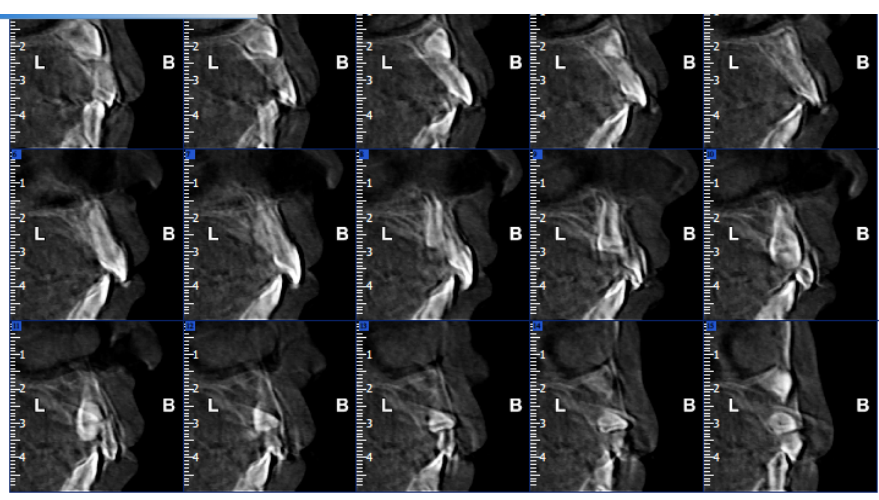

Figure 2. CROSS SECTIONS SHOW 2.1 ROTATED, 2.3 TRANSPOSED ON 2.2 LAYING

Right half palate is narrower and longer than the the left half - the midpalatal suture is deformed.

AFTER TWO MONTHS: Dental occlusion has been increased to let tooth 2.1 to extrude and so a bracket can be put on it (Figure 9)

In the upper arch there is a rapid palatal expander with right buccal extension to stop the tooth 1.1, while rotating the tooth 2.1 (Figure 10)

${ }^{\star}$ Correspondence to: Felice Festa, MD MSD PHD, Professor, via C.Colombo n 24 Formia, Italy, Tel: 08713554070; E-mail: ffesta@unich.it

Received: January 16, 2019; Accepted: January 23, 2019; Published: January 25, 2019 
Macrì M (2019) CBCT images of treatment of incisor rotation, canine transposition, lateral incisor orizzontal position and risk of canines impacted, as result of facial trauma in growing patient

Table 1. Initial chefalometric analysis

\begin{tabular}{|c|c|c|c|c|c|}
\hline GoGn- SN & $37^{\circ}$ & $32 \pm 5$ & ANG. INTERI & $127^{\circ}$ & $132 \pm 6$ \\
\hline FMA & $26^{\circ}$ & $22-28 \mathrm{M}$ & ANG. SELLA & $130^{\circ}$ & $122 \pm 5$ \\
\hline MM & $25^{\circ}$ & $28 \pm 6$ & ANG.ARTICO & $135^{\circ}$ & $143 \pm 6$ \\
\hline SNA & $81^{\circ}$ & $82 \pm 2$ & $\begin{array}{c}\text { ANG. GONIA } \\
\text { SUP } \\
\text { INF }\end{array}$ & $\begin{array}{c}131^{\circ} \\
56^{\circ} \\
75^{\circ}\end{array}$ & $\begin{array}{c}120 \pm 5 \\
50 \pm 2 \\
70 \pm 3\end{array}$ \\
\hline SNB & $75^{\circ}$ & $80 \pm 2$ & $\begin{array}{l}\text { +1 A Pog } \\
-1 \text { A Pog }\end{array}$ & $\begin{array}{l}6 \mathrm{~mm} \\
1 \mathrm{~mm}\end{array}$ & $\begin{array}{c}3,5 \pm 2 \\
2 \pm 2\end{array}$ \\
\hline ANB & $6^{\circ}$ & $2 \pm 2$ & $\begin{array}{l}\text { WITTTS RIC } \\
\text { WITTS REAL }\end{array}$ & $6 \mathrm{~mm}$ & $0 \pm 2$ \\
\hline $\begin{array}{c}\text { +I Sna-Snp } \\
\text { +I PFH } \\
\text { +I SN }\end{array}$ & $\begin{array}{l}111^{\circ} \\
112^{\circ} \\
100^{\circ}\end{array}$ & $\begin{array}{c}113 \pm 2 \mathrm{~B} \\
113 \pm 1 \mathrm{~B} \\
103 \pm 2\end{array}$ & $\begin{array}{l}\text { A-MC NAM } \\
\text { Pog-MC NA }\end{array}$ & $\begin{array}{l}3 \mathrm{~mm} \\
-4 \mathrm{~mm}\end{array}$ & \\
\hline IMPA & $96^{\circ}$ & 90-96 B & & & \\
\hline
\end{tabular}

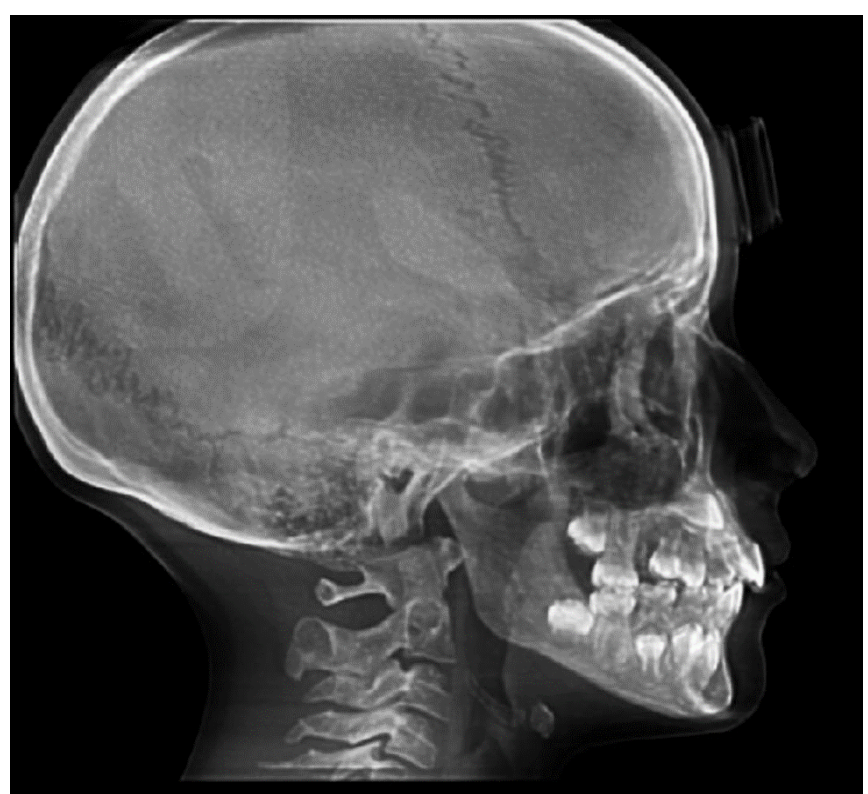

Figure 3. LATERAL CRANIUM RX

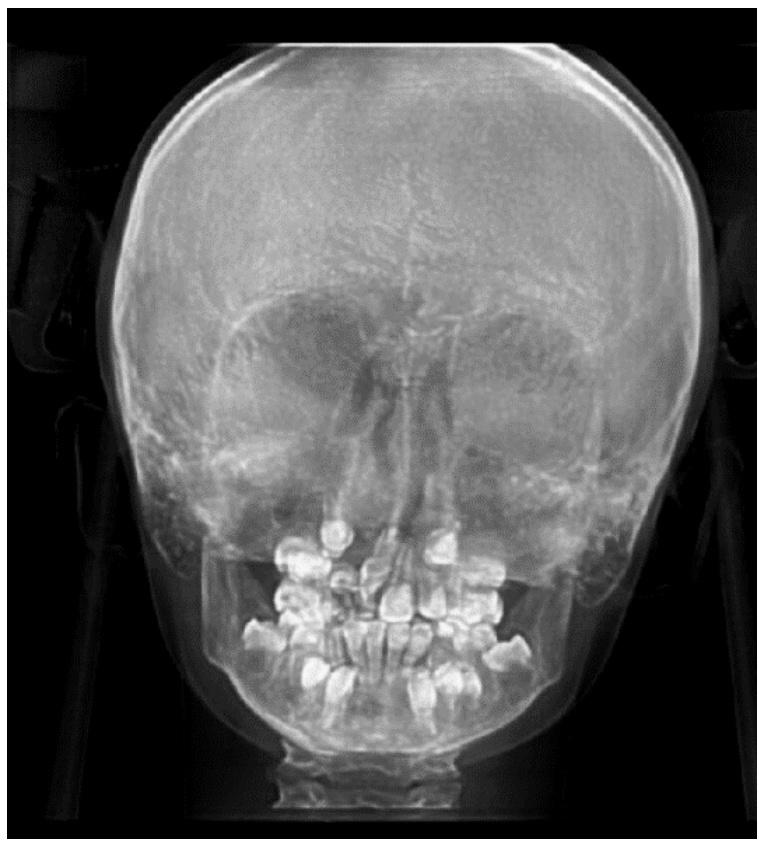

Figure 4. FRONTAL RX

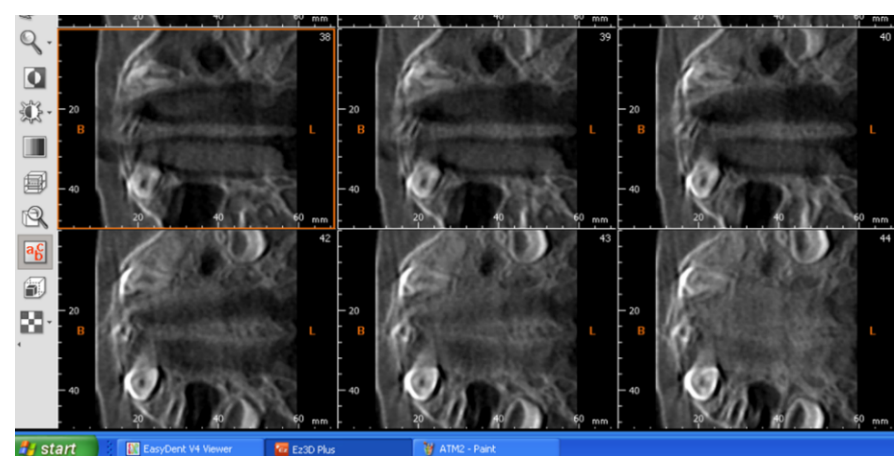

Figure 5. PALATAL SUTURE
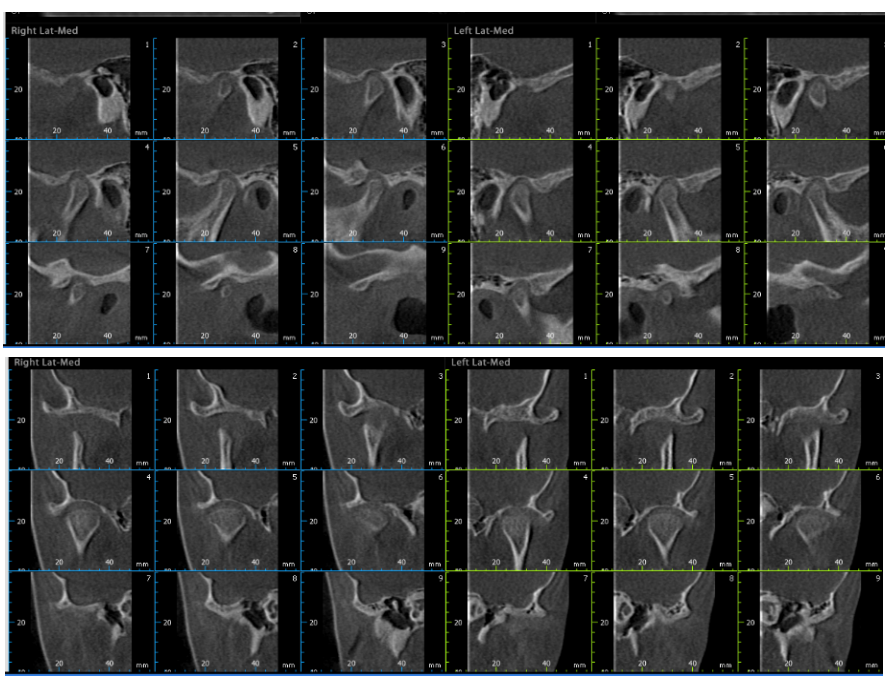

Figure 6. TMJ CROSS SECTIONS
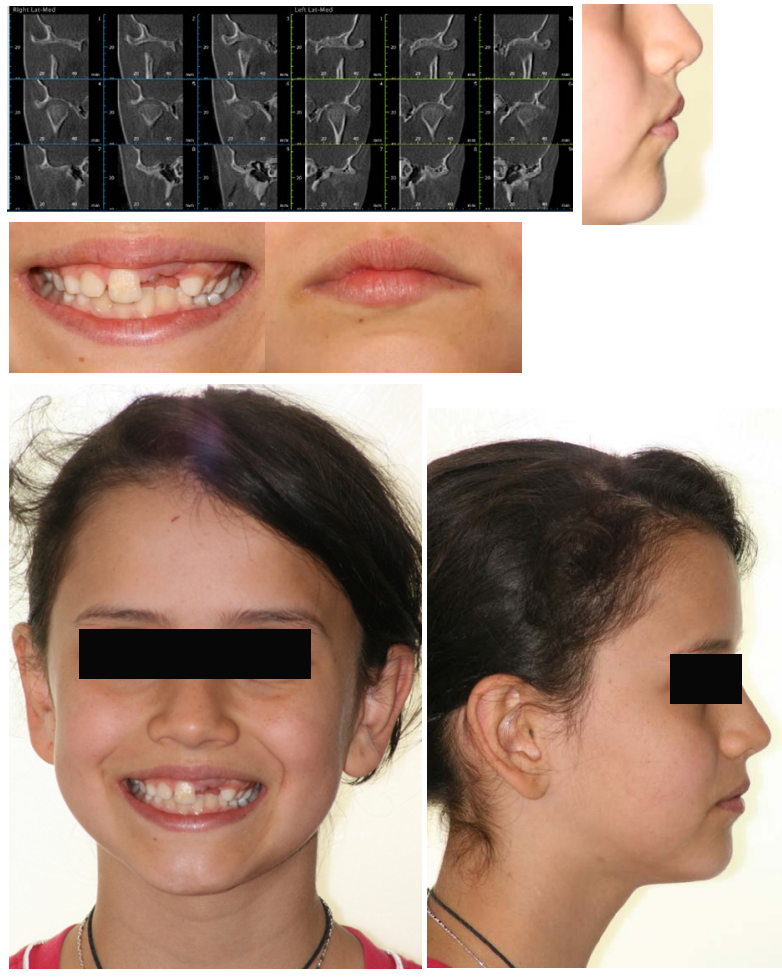

Figure 7. EXTRAORAL PHOTOS 
Macrì M (2019) CBCT images of treatment of incisor rotation, canine transposition, lateral incisor orizzontal position and risk of canines impacted, as result of facial trauma in growing patient
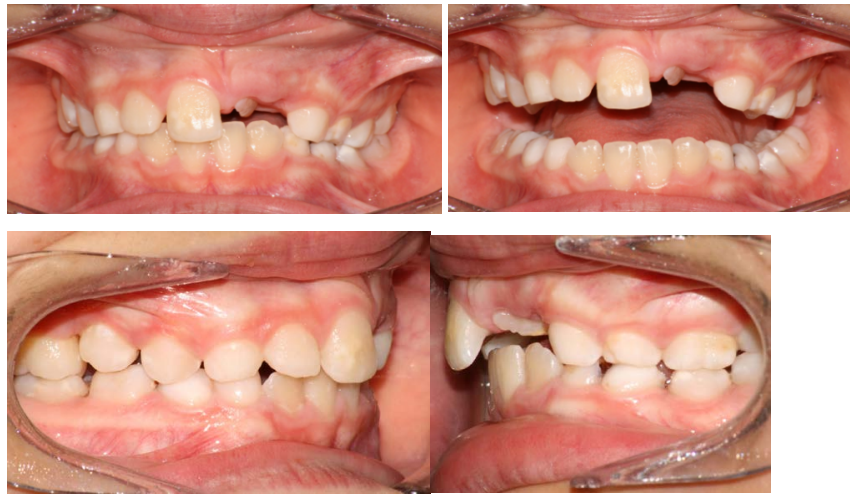

Right molar second class relationsheep, left molar first class relationsheep

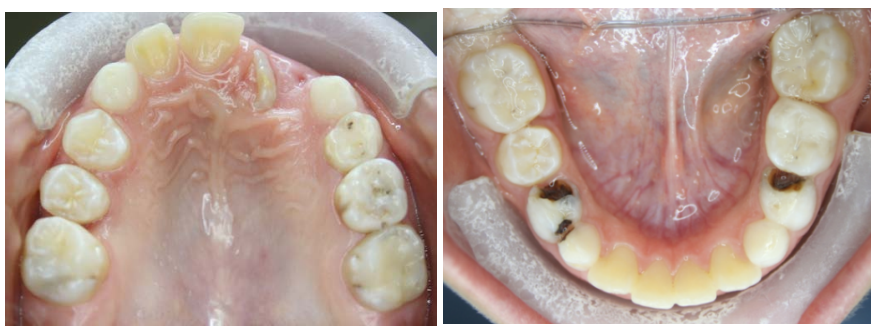

Figure 8. INTRAORAL PHOTOS

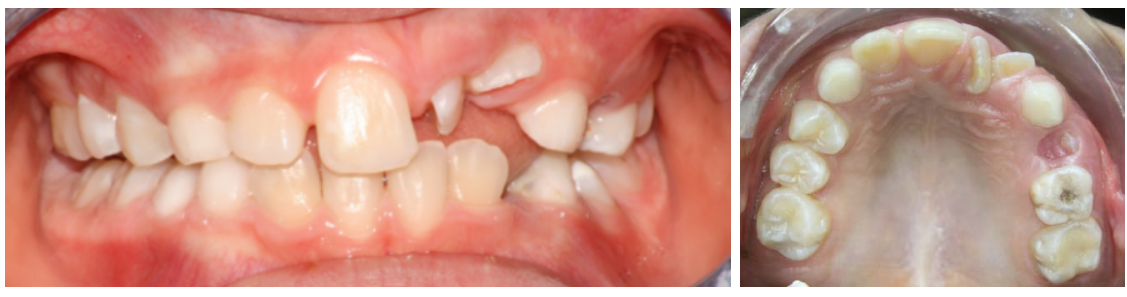

Figure 9. AFTER TWO MONTHS
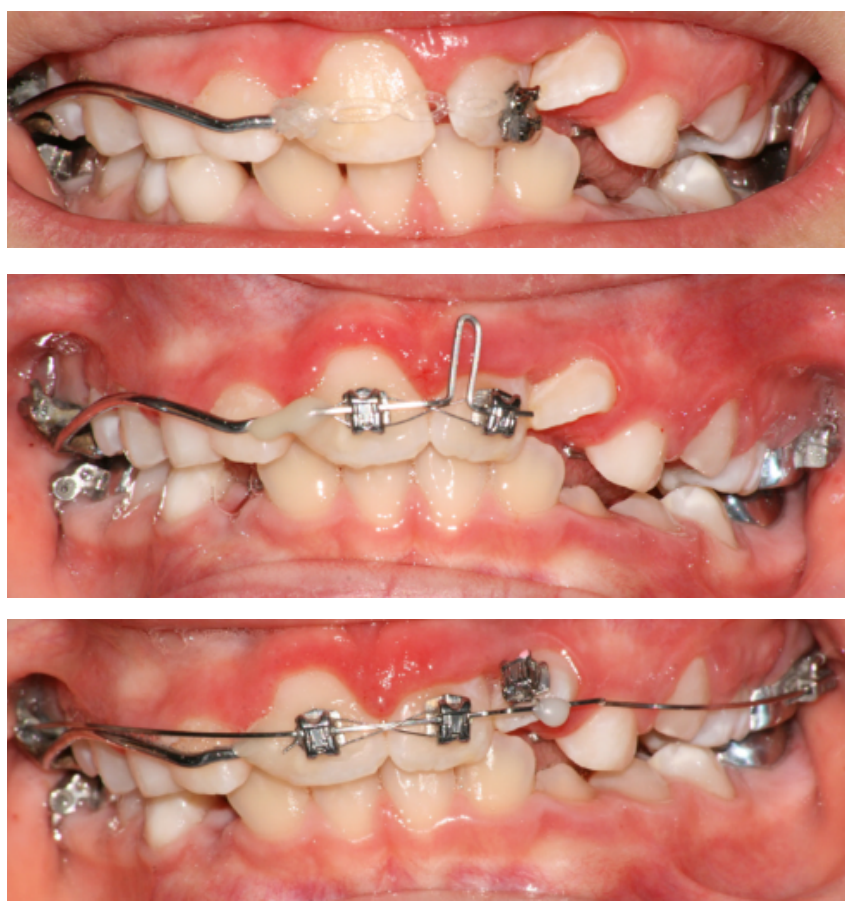

Figure 10. TOOTH 2.1 ROTATION 
Macrì M (2019) CBCT images of treatment of incisor rotation, canine transposition, lateral incisor orizzontal position and risk of canines impacted, as result of facial trauma in growing patient

The rapid palatal expander has been modified to pull down upper canines (Figure 11)

In 2015 brackets DAMON Q have been positioned in the upper arch, except on the tooth 2.2 and the tooth 2.3 has been exposed to put on it a botton (Figure 12)

A JIG, made of rectangular stainless steel wire, has been used to increase space for the tooth 2.3

Then the space has been managed using a coil between teeth 2.1 and 2.6 (Figure 13). The tooth 2.2 has been managed using an overlay wire (the bracket on the tooth 2.2 has been tipped to upright the root toward the midline and the bracket has been placed upside-down to let the root correct its torque when a rectangular wire is placed in the slot)
Then the tooth 2.3 has been managed using an overlay wire too and a lace back (Figure 14)

Intercuspidation elastics with a direction to correct the second class, have been positioned for almost a month (Figure 15)

After a year, photos in static and dinamic position, extraoral photos and CBCT images (Figures 16-19) and Table 2

\section{Discussion}

- Mandibular movements are ensured by good anterior guide

- Good face profile and teeth exposure during smile

- Good position of root between cortical alveolar bone (see cross sections)
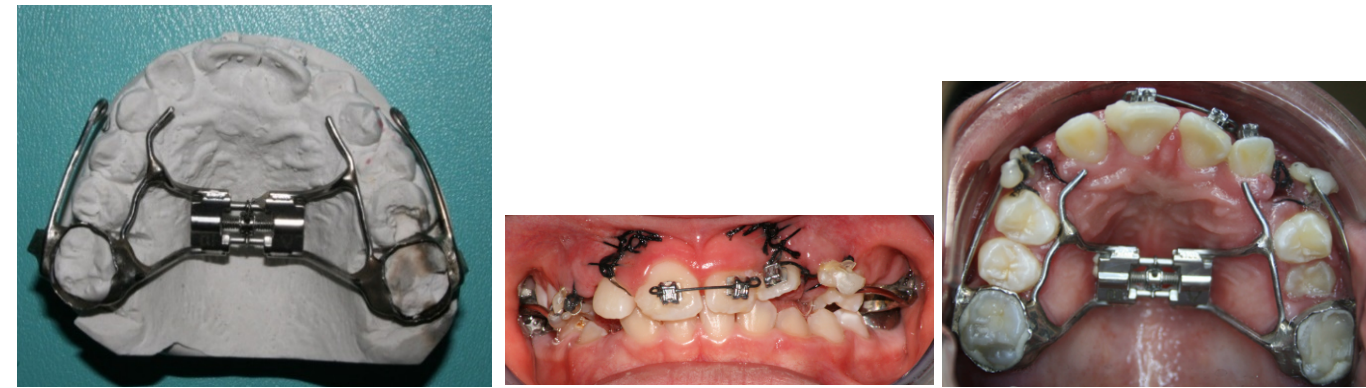

Figure 11. MODIFIED RAPID PALATAL EXPANDER

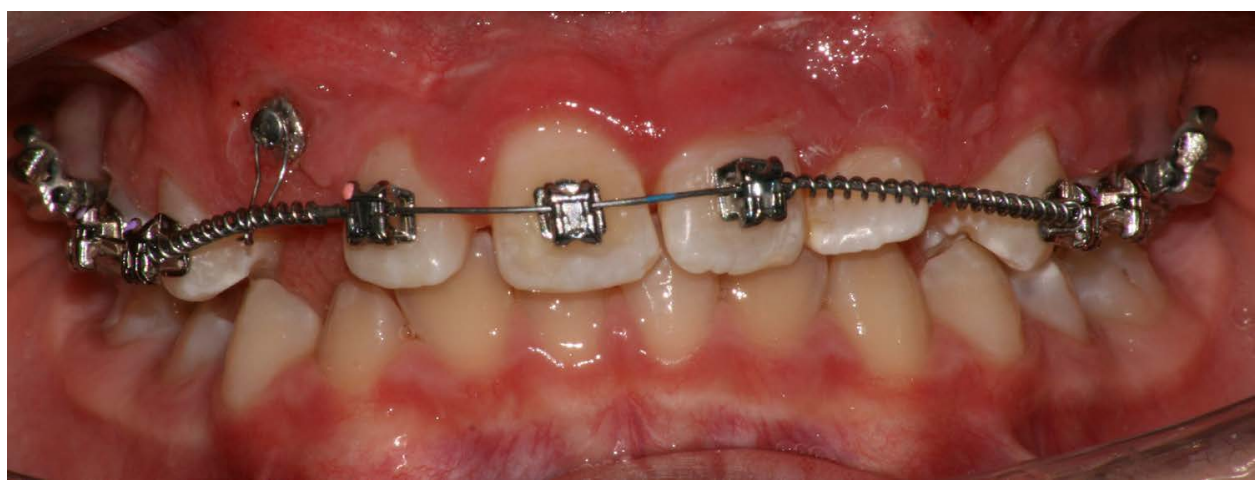

Figure 12. BRACKET DAMON Q
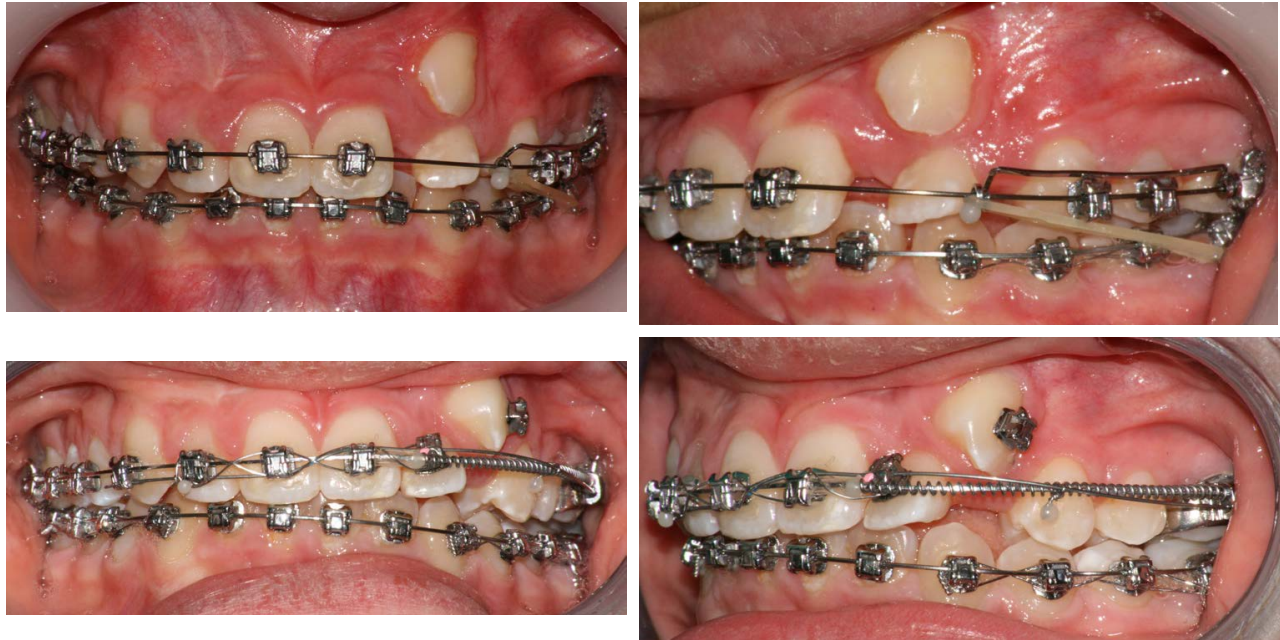

Figura 13. JIG AND COIL FOR SPACE 
Macrì M (2019) CBCT images of treatment of incisor rotation, canine transposition, lateral incisor orizzontal position and risk of canines impacted, as result of facial trauma in growing patient
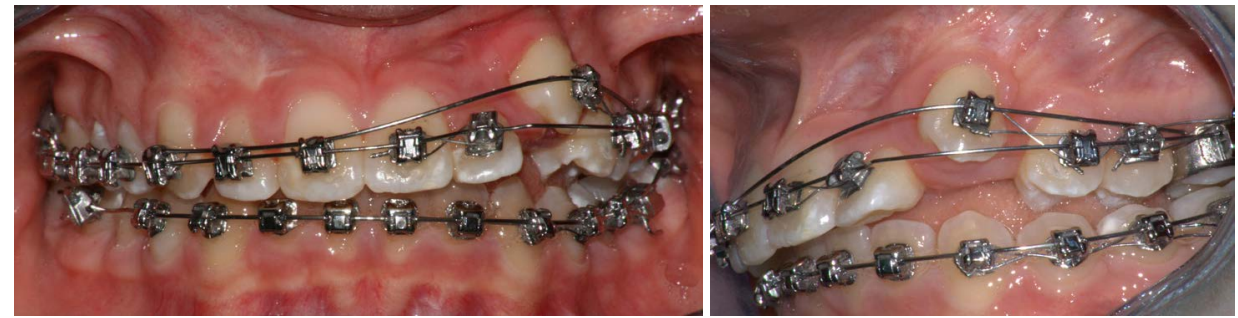

Figure 14. OVERLAY WIRE
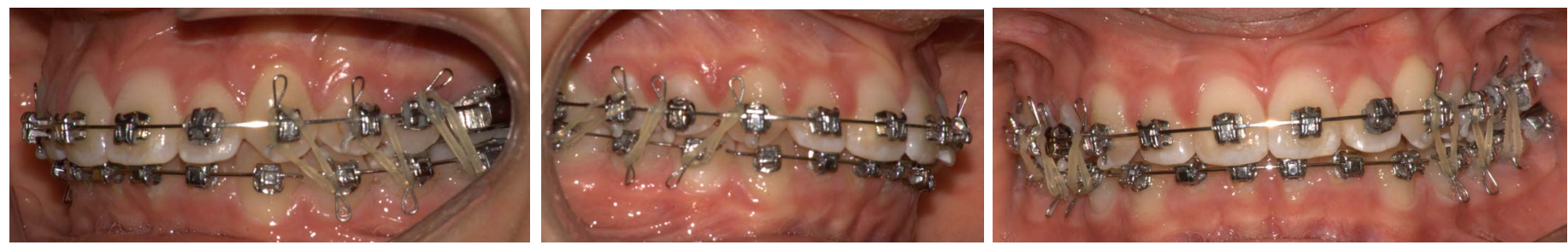

Figure 15. INTERCUSPIDATION ELASTICS
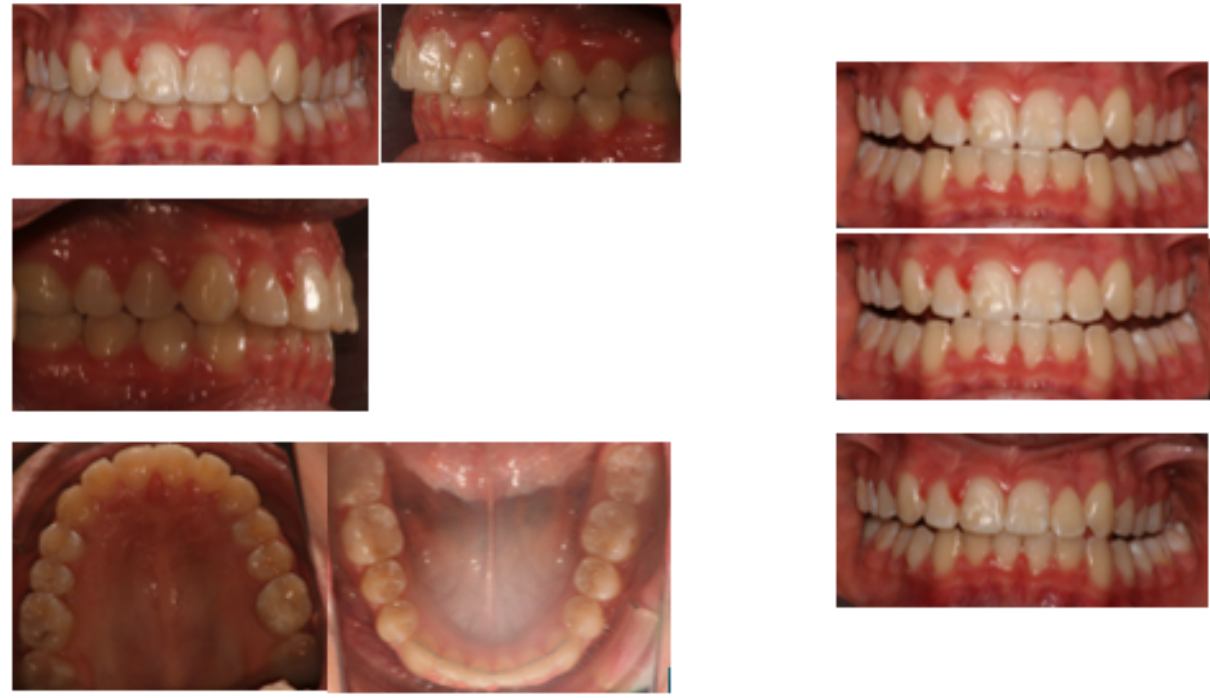

Figure 16. INTRAORAL FINAL PHOTOS
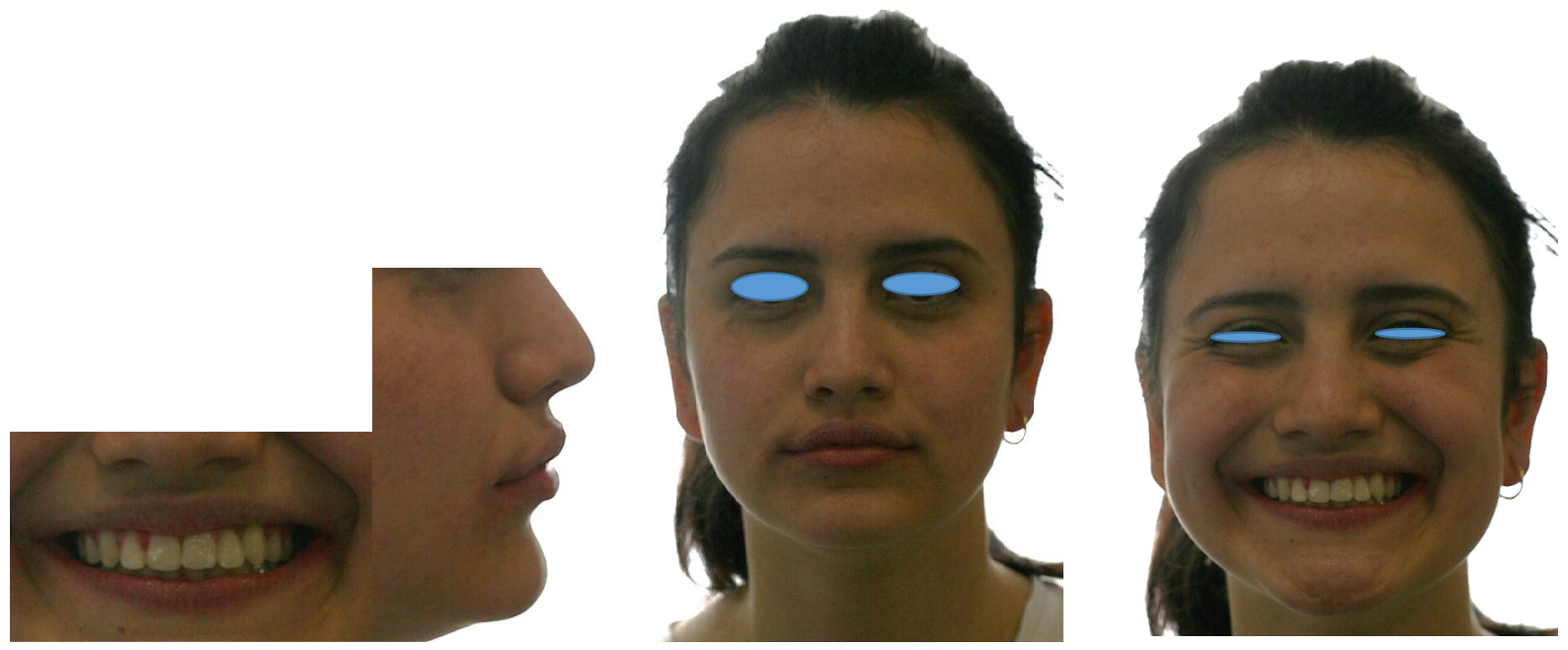

Figure 17. EXTRAORAL FINAL PHOTOS 
Macrì M (2019) CBCT images of treatment of incisor rotation, canine transposition, lateral incisor orizzontal position and risk of canines impacted, as result of facial trauma in growing patient

Table 2. Final chefalometric analysis

\begin{tabular}{|c|c|c|c|c|c|}
\hline GoGn- SN & $31^{\circ}$ & $32 \pm 5$ & ANG. INTERI & $124^{\circ}$ & $132 \pm 6$ \\
\hline FMA & $24^{\circ}$ & $22-28 \mathrm{M}$ & ANG. SELLA & $130^{\circ}$ & $122 \pm 5$ \\
\hline MM & $21^{\circ}$ & $28 \pm 6$ & ANG.ARTICO & $130^{\circ}$ & $143 \pm 6$ \\
\hline SNA & $83^{\circ}$ & $82 \pm 2$ & $\begin{array}{c}\text { ANG. GONIA } \\
\text { SUP } \\
\text { INF }\end{array}$ & $\begin{array}{r}132^{\circ} \\
56^{\circ} \\
76^{\circ}\end{array}$ & $\begin{array}{c}120 \pm 5 \\
50 \pm 2 \\
70 \pm 3\end{array}$ \\
\hline SNB & $79^{\circ}$ & $80 \pm 2$ & $\begin{array}{l}\text { +1 A Pog } \\
\text {-1 A Pog }\end{array}$ & $\begin{array}{l}4 \mathrm{~mm} \\
1 \mathrm{~mm}\end{array}$ & $\begin{array}{c}3,5 \pm 2 \\
2 \pm 2\end{array}$ \\
\hline ANB & $4^{\circ}$ & $2 \pm 2$ & $\begin{array}{l}\text { WITTTS RIC } \\
\text { WITTS REAL }\end{array}$ & $1 \mathrm{~mm}$ & $0 \pm 2$ \\
\hline $\begin{array}{c}\text { +I Sna-Snp } \\
\text { +I PFH } \\
\text { +I SN }\end{array}$ & $\begin{array}{l}121^{\circ} \\
119^{\circ} \\
110^{\circ}\end{array}$ & $\begin{array}{c}113 \pm 2 \mathrm{~B} \\
113 \pm 1 \mathrm{~B} \\
103 \pm 2\end{array}$ & $\begin{array}{l}\text { OB } \\
\text { OJ }\end{array}$ & $\begin{array}{l}3 \mathrm{~mm} \\
2 \mathrm{~mm}\end{array}$ & \\
\hline IMPA & $95^{\circ}$ & $90-96$ B & & & \\
\hline
\end{tabular}
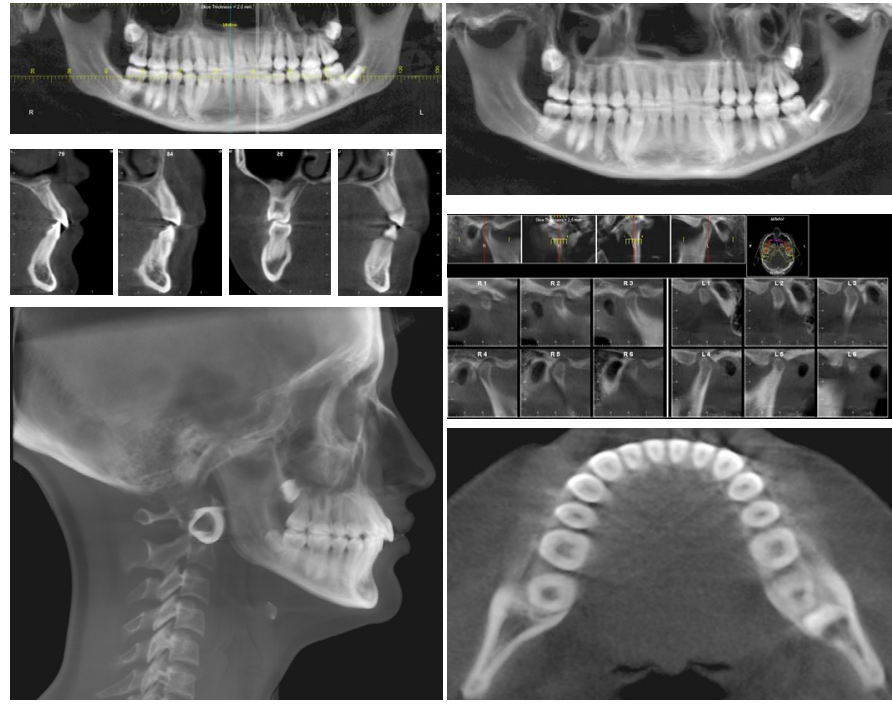

Figure 18. FINAL CBCT IMAGES

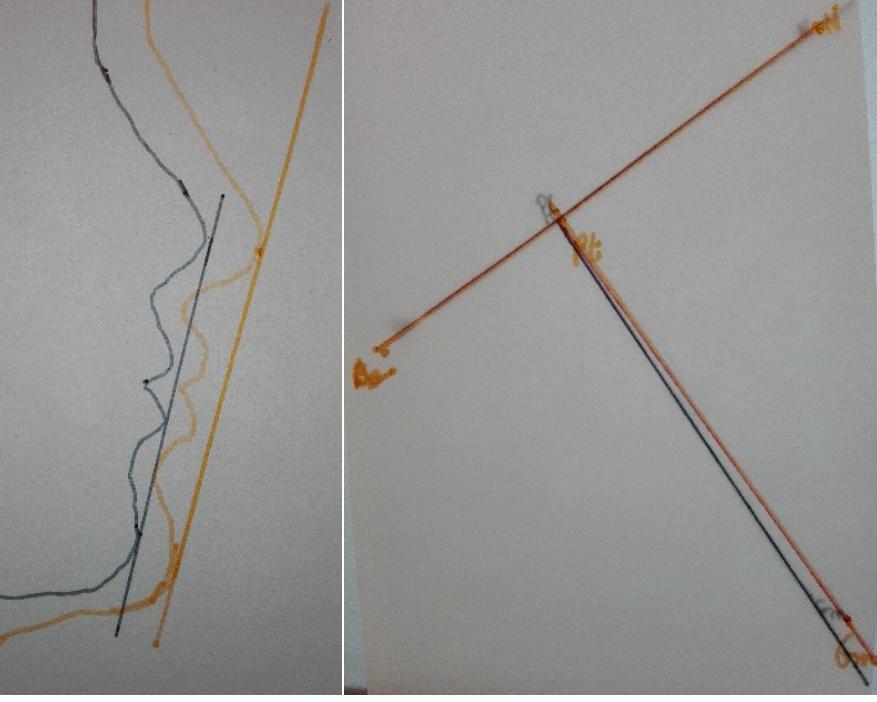

Figure 19. SUPERIMPOSITION (Na-Ba at $\mathrm{CC})$ and PROFILE
- The root and palatal face of crown of tooth 2.2, are not regular

- Initial and final cefalometric values are not chenged so much. The mandible has moved forward and upper incisors inclination is increased

- Each condyle is placed in the center of its fossa

- Dental arch has a regular and wide form

- Wisdom teeth should be extracted

\section{References}

1. Borgis KJ, Halsband H (1992) Three-dimensional evaluation of computerized tomography images of pediatric fractures. Langenbecks Arch Chir Suppl Kongressbd 1992: 390-395. [Crossref]

2. Proffit WR, Frazier-Bowers SA (2009) Mechanism and control of tooth eruption: overview and clinical implications. Orthod Craniofac Res 12: 59-66. [Crossref]

Copyright: (C2019 Macrì M. This is an open-access article distributed under the terms of the Creative Commons Attribution License, which permits unrestricted use, distribution, and reproduction in any medium, provided the original author and source are credited. 